\title{
A Linguistic Study of Praise with Reference to Arabic Religious Texts
}

\author{
Iman Khudhair Oda Al-Abodi \\ Department of English, College of Education, University of Al Qadisiyah, Diwaniya, Iraq
}

\begin{abstract}
This study explores praise as one of the expressive acts in Arabic. The love of praise is part of human nature and a sincere praise is an important tool in giving people confidence and hence making them feel happy and satisfied. The problem may increase when the speaker expresses his praise by using words of blame which might create some sort of ambiguity to the reader because he might understand it as blame rather than praise. For the sake of presenting and discussing the act of praising in Arabic, the present study aims at proving the linguistic devices of praise focusing on three aspects: pragmatic, semantic and syntactic in some religious texts. The theoretical part deals with investigating the pragmatic, semantic and syntactic aspects of praise as well as its types. The practical part deals with analyzing some religious texts taken from different aayas from different suras in the Glorious Quran. It is concluded that praise can be applied to religious texts depending on three aspects of language and Arabic language is distinguished by its heavy use of explicit and implicit forms expressing praise.
\end{abstract}

Index Terms - Linguistics, Pragmatics, Praise, Semantics, Syntax.

\section{PRAISE : A PRAGMATIC PERSPECTIVE}

$\mathrm{Al}$ madh 'praise'in Arabic is defined by Abn Manthur (1955) as an expression of commendation and it is the opposite of blame.

Etymologically, the verb madh and it is derivatives (madahaan and mudaha ) come from the word tamadah which means either 'he praises himself' or 'people praise each other', from the word aimtadah meaning 'extend', and tamadah meaning 'the opposite of blame' (Al Manjad fi allugha, 1969).

The explicit performative verbs such as namaa 'to be good', and habtha 'lovely' as well as the implicit ones like fahum, karam, sabaq are considered by Arab rhetoricians as nonrequestive performative verbs.

Pragmatically speaking, Hassan (n.d., p. 367) states that in Arabic there are certain performative verbs that can be used to denote praise, some of these are explicit like aimdah 'praise', athnaa 'commend', and aistahsan 'approve' as well as certain expressions of praise such as aljamil 'beauty', aleathim 'great', alfadil 'honest', almajid 'glorious', etc. :

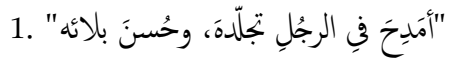

I praise the man for his patient and well-done.

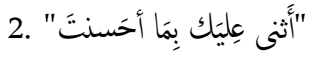

I commend you for what you did.

On the other hand, there are some implicit performative verbs which are in need of certain devices to refer to the act of praising such as negative, interrogative, and exclamative. For instance, when people talk about a certain person for his characteristics and virtues, they may say:

3. a. "مَا هَذا بِشَرَاً ؟َ" What is this man ?

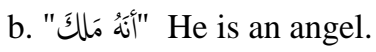

In addition to the explicit verbs of praise mentioned earlier, there are two other verbs namaa 'to be good', and habtha 'lovely' (Al Aistirabadiu, n.d., p. 311):

4. "نِنْمَ الرَّجُجلُ زَيْدُ"

What an excellent man Zaid is!

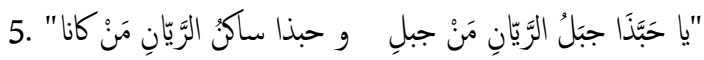

Praise, here can be directed to the external features of somebody or something which is praiseworthy. For Nahr (1978, p. 263) these explicit verbs of praise have their values in Arabic sentence since they have certain constructions which cannot be found in other languages. Al Firuzabadi (1970, p. 89) states that verbs of praise are different from other Arabic verbs for they normally occur in the construction that consists of three basic forms:

Verb of praise + Subject + (المخصوص بالمدح) 'What is praised':

6. "نِعْمَ الصديقُ حسنُ"

What an excellent friend Hassan is! (Bybrs and Sawid, 1984, p. 367)

The perfect verb namaa is explicit, intransitive, and it must have a subject (Al Eayniu, 1990, p. 22). Hence, Arab rhetoricians like albasriuwn believe that verbs of praise should be perfect and stative that have neither imperfect (i.e., present) nor future tense and they have the same form in masculine and feminine (Al Sabuniu ,n.d., p. 277).

Thus, the verb namaa takes the masculine form in preference to the feminine, even when the subject is feminine by signification (Wright, 1967, p. 290):

Journal of University of Human Development

Volume 5 No. 3(2019); DOI: 10.21928/juhd.v5n3y2019.pp108-115

Regular research paper: Published 23 July 2019

Corresponding author's e-mail: imanalboudi@yahoo.com

Copyright (C) 2019 Iman Khudhair Oda Al-Abodi. This is an open access article distributed under the Creative Commons Attribution License

(CC BY-NC-ND 4.0) 


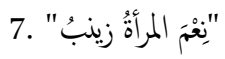

Zeineb is an excellent woman! rather than نِمَتْن

Arab rhetoricians and grammarians like Bin Yaeish (n.d., p. 130), Al Mubarid (1979 ,p. 141) and Al Jurajaniu (1982, p. 363 ) agree that the subject of the verb namaa is of two types:

The first type consists of the explicit noun with either the definite article (أل), as in (8) or is added to another noun with the definite article (أل), as in (9):

8. "

What a wonderful man Abdullah is!

9. " مِنْمَ غلامُ الرجلِ عمروُ

What a wonderful son of man Amro is!

The second one consists of the implicit noun which is explained by indefinite accusative:

"نِعْمَ رجلاً عبدُ اللهِ" 10.

What a wonderful man Abdullah is!

The subject, here is implicit (i.e., alrajul) which can be explained by indefinite accusative (rajulan)'man'.Then, the original sentence becomes (نْعْمَ الرَجلُ رجلاً عبدُ اللهِ).

For Ibn Asfour (1986, p. 73) the verb namaa differs from other verbs in that it should have after it is subject a nominative noun which is called by Arab rhetoricians المخصوص بالمدح a what is praised'. It is a nominative noun that may occur either after the explicit performative verb and it is subject as in (11) or before it as in (12) and it may refer to somebody or something that deserves praise (Makram, 1975, p. 54):

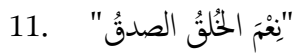

What an excellent virtue truth is!

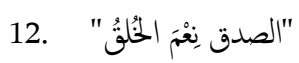

Truth is an excellent virtue, indeed!

Also Hassan (n.d., p. 377) mentions that المخصوص بالمدح should be either a definite or indefinite noun specialized of description, and it should be more specific than the subject, and agree with it in gender and number. Moreover, it must occur after the subject if it is an implicit noun:

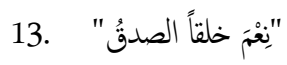

What an excellent virtue truth is!

Arab rhetoricians and grammarians like Bin Al Hajib (1980, p. 376) and Al Jurjaniu (1982, p. 371) agree that المخصوص may be deleted if there is some expression in front of it is sentence that refers to it:

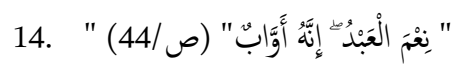

How excellent in Our service! Ever did he turn (to Us)!" (Ali, 2001, p. 1171)

In this aaya, المخصوص is deleted since his story has been mentioned earlier, so the original aaya is (نُعْمَ العَبْدُ هُو which means Jop. Bin Yaeish (n.d., p. 135).

Meanwhile, Wright (1967, p. 98) refers to another explicit performative verb of praise that is حَبَّ or or to be pleasing or charming' (contracted from حَبُبَ). This verb is frequently combined with the demonstrative $\dot{ }$ and forms the indeclinable
حَبَّنَ which is used to praise somebody for he is very close to the heart.

The verbs habtha and namaa similar to each other, but they differ in their forms in which habtha comprises of the verb and subject toghter. Originally, the perfect verb حبّ has two expressions which are حََبَتَ أحَبَبت , أحَبَبتَ commonly used Bin Yaeish (n.d., p. 138). For instance: the Prophet Muhammad says:

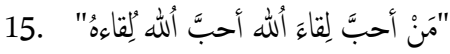

The one who loves to meet Allah, Allah Loves his meeting.

According to Al Baghdadi (n.d., p. 122) حبَبتَ is a transitive verb which can be exemplified by Al Nahshiliu:

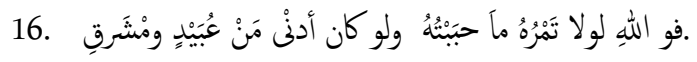

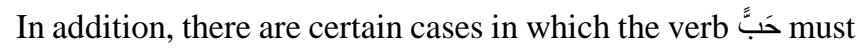
satisfy if it used as a verb of praise Al Raajihiu (1985, pp.32425):

First: it must have a subject, which is the demonstrative ذا:

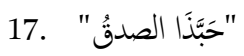

How lovely truth is!

Al Anbary (n.d., p. 109) and Bin Al Hajib (1980, p. 377) agree that the subject ذَ of the verb has one form in the dual, plural, and feminine:

18. a. "حَبًَّا الزبّيدانَ"

How lovely the two Zaids are!

b. "حَبَّذا الزّيَدونَ"

How lovely the Zaids are!

Second: if it is subject is the explicit noun other than the demonstrative 1 , it will not keep one form, but it will change according to context. It may come as singular, masculine or feminine and with "ba' zayida" (Hassan, n.d., p. 383):

19. a. " aَبّ المضىءء القمرُ

How bright the moon is!

b. "ححََّتْ المُضيئاتَ الخَقَمَارُ"

How bright the moons are!

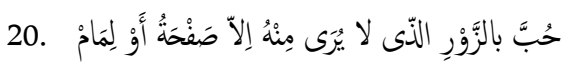

Third: sometimes it is subject may come as an implicit noun which is explained by indefinite accusative Al Raajihiu (1985, p. 326):

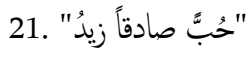

How truthful Zaid is!

Concerning المخصوص بالمدح with the explicit verb habtha, it is said that it must not occur in front of neither its subject alone nor its verb and subject together, it is wrong to say (حَبَّ علىّ ذا (على)), or (على حَبّذا) since its occurrence before its verb and subject is not allowed in Arabic so its occurrence after the verb of praise and its subject remains a fixed form (Al Ainsari 1996, p. 182). But it may occur before or after the indefinite accusative such as: 


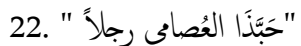

The self-made man is wonderful, indeed!

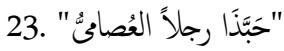

The self-made man is wonderful, indeed!

Moreover, the act of praising in Arabic can be expressed implicitly by certain verbs of the form faeal . Al Ainsari (1996, p. 180) affirms that the implicit verbs of praise are formed only from triliteral verbs of the form fael expressing exclamations either originally like sharaf, tharf or transformation like fahum, darab. Then, it can be used just like verbs of praise with all their cases concerning the subject and المخصوص. Yet Arab rhetoricians differ concerning the use of such verbs. Al Farisi and many others consider them as verbs of praise, while others like Al Akhfish and Al Mubrid consider them as verbs of exclamation (Bin Hian, 1989, p. 27).

However, such implicit verbs of the form faeal are used as verbs of praise for two main reasons:

First: every Arabic verb of the form faeal can be considered as a verb of manners and may refer to adjectives of quality like beauty, great, good, etc. which are associated with the praisee (Al Aistirabadiu, 1975, p. 74).

Second: the triliteral verbs of this form are used to refer to praise in specific, while the explicit ones to praise in general (Anys, 1966, p. 39).

These implicit verbs of the form faeal differ from the explicit ones in three cases as follows (Hassan, n.d., p. 389):

1. They differ in their meanings, and this is reflected in two ways:

a. the implicit verb of the form faeal has an exclamatory meaning,

(Al Mubarid, 1979, p. 147), e. g., if somebody says:

24. "فَهُمَ المعلُُ أحمدُ

Ahmad is an understanding teacher, indeed!

he means: (أفَهَ أحَمداً). What understanding teacher Ahmad is!

b. it can be used for praise in specific, while the explicit for praise in general (Bin Al Hajib, 1982, p. 96).

2. They differ in their explicit subjects in two ways

(Al Ainsari, 1996, p. 180):

a. the subject of the implicit verb of the form faeal

may not have the definite article (أل):

25. "فَهَهْ زَيْدُ

How understanding Zaid is!

whereas the subject of the explicit verbs must be defined by the article (أل).

b. it is commonly used with"ba' zayida" (Hassan, n.d., p.388):

26. " مَحُدَ بالجارِ معاشرةً

What a praiseworthy companion-ship of a neighbour! It means: حَمْدَ الجار معاشرةً

3. They differ also in their implicit subjects in two ways:

a. the subject of the implicit verb of the form faeal may refer to what preceds it, or b. it may be associated with what follows it:

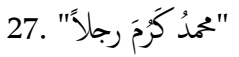

How a generous man Muhammad is!

Here, the implicit subject of the verb karam " كرُمَ" may refer either to (man) or to (Muhammad) (Al Khdry, 1940, p. 45).

\section{A. Praise by Blame}

Arab rhetoricians speak about praise by blame and blame by praise together since both follow the same rhetorical style when someone says something and means another. Ibn Al-Mu'taz is the first Arab rhetorician that pays attention to this kind of speech and calls it praise by blame. Others call such art of speaking as Al Aistithna' 'exception' for it is beauty comes from certain exception devices (Ateeq, 1970, p. 156 and Matlub and Al Basir, 1999, p. 446).

Al Maraghi (n.d., p. 354) and Al Qazwaini (n.d., pp. 372-73) mentions three different types of praise by blame:

The first type, more rhetorical than others, is formed by excluding bad features from somebody/ something, then praising him/it by referring to good characteristics after using exception device (Al Hashmi, 1970, p. 382):

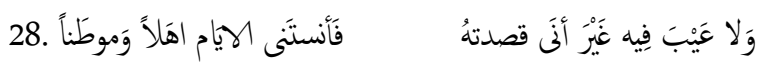

The second type is used to emphasize praise for somebody/something. It consists of exception device which is preceded and followed by good characteristics (Al Qazwaini, 1904, p. 381):

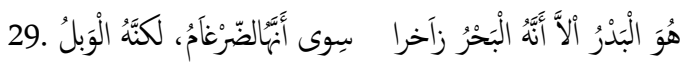

(Matlub, 1964, p. 245)

In (29), the poet praises his praisee by describing him as a moon and after using exception devices, he completes his description by saying he is just like a rich river, and a brave lion (Ateeq, 1970, p. 159).

The third type, less common, is formed only by using the exception (Al Qazwaini, n.d., p. 374 and Al Maraghi, n.d., p.355):

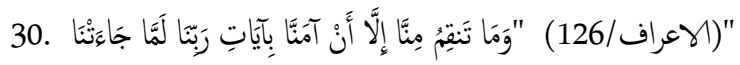

"But thou dost wreak. Thy vengeance on us. Simply because we believed

In the Signs of our Lord. When they reached us!" (Ali, 2001, p. 378)

Here, the exception $\stackrel{\mathrm{V}}{\mathrm{l}}$ is used in order to praise those who are true believers in His aayas after blaming (Al Suyuti, 1380, p. 228).

\section{B. Blame by Praise}

Blame by praise according to Ateeq (1970, p. 162) and Matlub (1980, p. 374) consists of the following two types:

The first type is used to exclude good features from somebody/something in order to blame him/it by referring to bad characteristics:

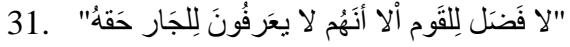

The folk have no virtue but they devalue the neighbour.

In (31), the speaker wants to blame certain people by excluding good features from them and mentioning their bad feature after using the exception ${ }^{\prime}$ ' 'but'. In this type, the 
speaker deceives the listeners for when they hear this kind of speech, they think that he praises them, but in fact he blames them by praising (Al Jazem and Amin, 1969, p. 155).

The second one is formed by using the exception device that is preceded and followed by bad characteristics (Matlub and $\mathrm{Al}$ Basir, 1999, p. 448):

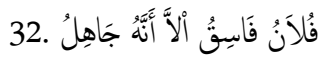

(Al Tifatazaniu, n.d., p. 181)

$\mathrm{X}$ is vicious but he is ignorant.

From the above discussion, one can say that the rhetoric of praise by blame and blame by praise is built on deceiving the listener since he understands something, but the speaker means another.

\section{The SEMANTIC IMPLiCATION OF PRAISE}

There are certain lexical items belonging to different classes (parts of speech) which are used to express praise. Semantically, praise can be realized by a number of expressions such as adjectives, verbs, and nouns. As for adjectives, the expressions used to refer to the act of praising are numerous such as:

'Umat,'awaab, bar, hakim, halim, hanif, khashie, rashid, sabir, and sadiq. Some of these expressions can be clarified by reference to certain aayas from the Glorious Quran.

'Umat 'people' is one of these expressions that can be used as an adjective. It has certain meanings in the Glorious Quran that denote praise and commendation. One of these is its reference to a group of people who are described as the best believers:

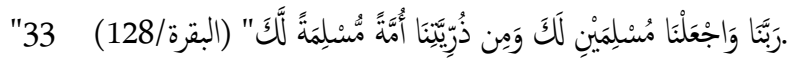

"Our Lord! make of us. Muslims, bowing to Thy (Will),

And of our progeny a people. Muslim, bowing to Thy (Will)" (Ali, 2001, p. 53)

In this aaya, Allah praises such good people for their obedience to His orders and their belief in His fate which are considered good featuress that deserve praise (Bin Qutaiba, 1978, p. 108).

Another adjective of praise is 'awaab 'turnover'. It is used in certain aayas in the Glorious Quran to refer to special features of Prophets and good people (Abdul Baqi, 1959, p. 57):

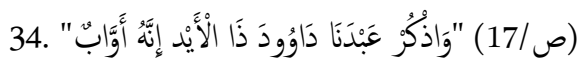

"Say, and remember Our Servant. David, the man of strength:

For he ever turned (to Allah)." (Ali, 2001, p. 1164)

The expression 'bar 'beneficent' is also used semantically as an adjective to refer to commendation (Abdul Baqi, 1959, p. 117):

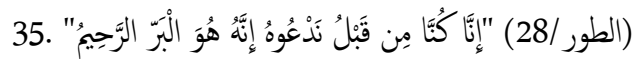

"Truly, we did call. Unto Him from of old: Truly it is He,

The Beneficent, the Merciful!" (Ali, 2001, p. 1371)

'bar is used to refer to the special feature of Allah since He is the Greatest Recompense and $\mathrm{He}$ is indeed good-the Beneficent, the Merciful.
As for verbs, the expression 'aman and it is derivatives yaman and amanaa are used in the Glorious Quran as intransitive in (36) and transitive verbs in order to praise the believers of Allah and His Messengers in (37) (Al Jawhari, 1979, p. 150):

36. البقرة/126) " "رَبِّ اجْعَلْ هَنَا بَأَدا آمِنًا

"My Lord, make this a City. Of Peace," (Ali, 2001, p. 53)

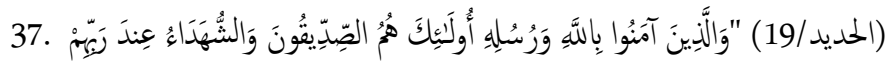

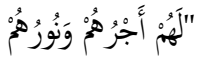

"And those who believe. In Allah and His messengers-They are the Sincere

(Lovers of Truth, and The witnesses (who testify), In the eyes of their Lord:

They shall have their Reward.And their Light." (Ali, 2001, p. 1425)

The verb sabah and its derivative yusabih are used in many forms in the Glorious Quran to praise Allah's name (38) and to praise Him by His angels (39):

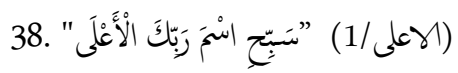

"Glorify the name. Of thy Guardian-Lord. Most High," (Ali, 2001, p. 1636)

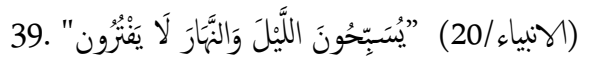

"They celebrate His praises. Night and day, nor do they.Ever flag or intermit" (Ali, 2001, p. 798)

Here, Allah describes His angels as excellent praisers who praise Him day by night without stopping (Al Asefahani, n.d., p. 221).

Faz 'attained' is another verb used to praise those who obey Allah and His Messenger because they attained real spiritual desire i.e., nearness to Allah.

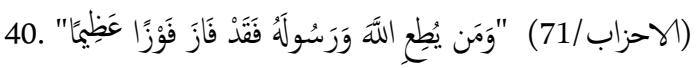

"He that obeys Allah. And His Messenger, has already. Attained the highest Achievement" (Ali, 2001, pp. 1079-80).

In addition to adjectives and verbs, nouns can also give the meaning of praise and commendation. The expression 'awaah 'compassion' is used when someone feels pain and grief, but it can be used in the following aaya to give another meaning (Bin Zakaria, 1979, p. 163):

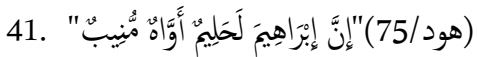

"For Abraham was, Without doubt, forbearing (Of faults), compassionate,

And given to look to Allah." (Ali, 2001, p. 531)

Allah praises His Prophet Abraham since he, like Muhammad, had three qualities in a pre-eminent degree, which are: he was long-suffering with other people's faults; his sympathies and compassion were very wide; and for every difficulty or trouble he turned to Allah and sought Him in prayer (Ali, 2001).

Huda 'guidance' is another noun used to praise those who receive guidance and whose spiritual advancement is progressive (Al Mubarid, 1937, p. 194) :

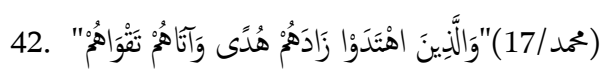


"But to those receive. Guidance, He increases. The (light of) Guidance,

And bestows on them. Their Piety and Restraint (From evil)." (Ali, 2001, p. 1319)

Nouns are also used in similes to denote the implicit praise through a particle (كأن):

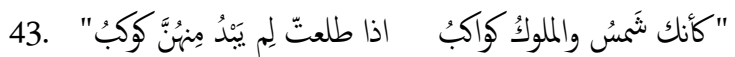

(Matlub and Al Basir, 1999, p. 119)

\section{The Syntactic Structure OF Praise}

Syntactically, praise can be realized by two basic sentence types: declarative and interrogative.

\section{A. Declarative}

Declarative sentences can be used to express many illocutionary forces such as praise, blame, warning, wish, prohibition, promise and threat (Matlub and Al Basir, 1999, p. 118):

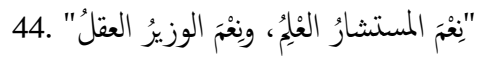

What an excellent counselor knowledge is, and what an excellent minister mind is!

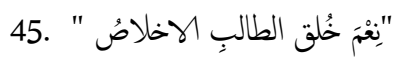

What an excellent virtue of student sincerity is!

Praise is carried out heavily by certain patterns of declarative sentence to express the speaker's commendation of someone or something. These patterns can be illustrated as follows:

First: The Verb of Praise + Subject with Definite Article (أل)

فعل المدح + الفاعل المعرف بـ (أل)

This pattern consists of the verb of praise which is either explicit

or implicit and a subject that must be defined by the article (أل). Al Zajaji (1988, p. 108)

states that the association of the verb with its subject is like that of an adjective with its noun. So this syntactic pattern is used to give approval and commendation to the praisee:

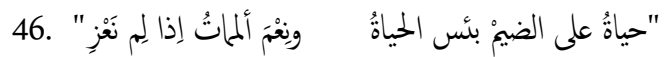

(Hassan, n.d., p. 370)

In addition, this pattern can also be used to express implicit praise by using the triliteral verb of the form faeal (فَع):

47. " "سَبُقَ الفِيلسوفُ وَفَهُمُ (Hassan, n.d., p. 172)

What a precedent in understanding the philosopher is!

Second: The Verb of Praise + Subject + Noun with Definite Article (أل)

$$
\text { فعل المدح + الفاعل المضاف الى ما فيه (أل) }
$$

Al Mubarid (1979, p. 43) and Ibn Al Siraj (1987, p. 122) agree that the subject which must be added to another noun with definite article (أل) is just like the subject that must be defined by such an article. Thus, the subject of this pattern looks like that of the first one since both of them refer to the praisee in general:

48. "نِنحَ عُقْتَى الكُرَكَاَ" (Ibn Aqil, 1965, p. 161)

How good the final attainment of the generosity is!

49. "عَدُلَ حُكُم الحَكِكِ".

The judge did justice, indeed!

In (49), one can see that the implicit verb of the form faeal is used to praise the judge with exclamatory meaning for his justice (Hassan, n.d., p. 386).

Third: The Verb of Praise namaa+Subject+ an Indefinite (أل): فعل المدح نِعْمَ + الفاعل المضاف الى Noun + Definite Noun with الدضاف الى ما فيه (أل)

This pattern, less common than others, is used only with the explicit verb namaa (نمعْمَ) followed by subject that must be added to an indefinite noun followed by another definite noun with (أل) (Hassan, n.d.):

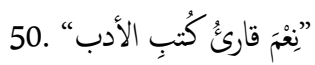

What an excellent reader of literature is!

Fourth: The Verb of Praise namaa+ Subject with Definite Article (أل) + Adjective:

$$
\text { فعل المدح نِنْمِ + الفاعل المعرف بـ (أل) + الصفة }
$$

This pattern is formed by the explicit verb namaa and subject with definite article (أل) in addition to adjective:

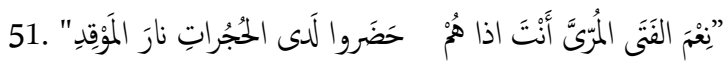

(Al Baghdadi, n.d., p. 112)

Fifth: The Verb of Praise of the Form faeal+Definite Subject+an Indefinite Accusative :

فعل المدح على وزن (فَعُلَ) +فاعل معرفة محضة+تميز

This pattern, rarely used, consists of the implicit verb of the form faeal and definite subject which is followed by an indefinite accusative:

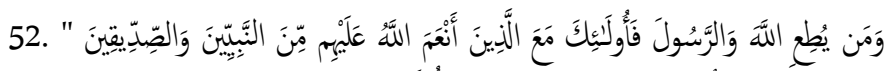

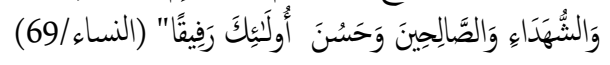

"All who obey Allah. And the Messenger. Are in the Company.Of those on whom

Is the Grace of Allah-Of the Prophets (who teach),The Sincere (lovers of Truth),

The Witnesses (who testify), And the Righteous (who do good):Ah! what a beautiful Fellowship! (Ali, 2001, pp. 205-06)

According to most Arab grammarians, the demonstrative

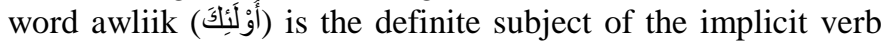
hasan (حَسُنَ) instead of the noun since its verb implies an exclamatory meaning, i.e., (مَا أحْسَنَ أَوْلَكِكَ رَفِيقَاً)

(Ibn Asfour, 1980, p. 68 and Al Salili, 1986, p. 593).

As for the indefinite accusative rafiqan (رَفِيقاً). However, the purpose behind using such pattern is to praise the group of

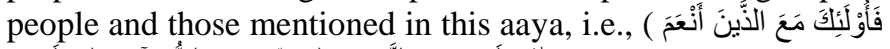

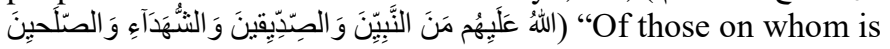
the Grace of Allah of the Prophets, the Sincere, the Witnesses, 
and the Righteous". That is why the implicit verb of praise is used with the demonstrative (Al Qaisi, 1975, p. 201).

Sixth: The Verb of Praise + Implicit Subject + an Indefinite Accusative:

$$
\text { فعل المدح + فاعل مضمر + تمييز }
$$

This pattern consists of the explicit verb of praise namaa and the implicit subject that must be explained by an indefinite accusative (Hassan, n.d., p. 370):

53. "نِعْمَ قَمَاً العَربُ"

What good people Arabs are!

The implicit subject, here the pronoun so 'they', refers to the praisees and must be explained by the indefinite accusative قومَا 'people'. The original sentence is:

نِنْمَ القومُ قومَاً العَربُ.

Seventh: The Verb of Praise namaa + Implicit Subject + (ما) 'What' or (ن) 'Who' + Verbal Sentence :

فعل المدح نِنََْ + فاعل مضمر +ما او من+جملة فعلية

In this pattern, the implicit subject of the verb of praise namaa is expressed by (ما) 'what'or (من) 'who' that is followed by verbal sentence instead of (المخصوص) Al Salili, 1986, p. 591):

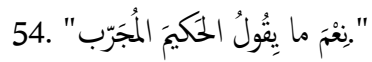

What a perfect talk of a wise man is!

55. "نِنْمَ مَنْ تصحَبهُ عِزيزاً

Who a wonderful companion is the dear!(Hassan, n.d., p. 372)

\section{B. Interrogative}

Syntactically, praise can be carried out by interrogative sentences since interrogation is used to perform certain illocutionary forces like the speech act of praising explicitly as well as implicitly. For instance: Al Ansari, Jarir, and Al Bahtari say in the following lines respectively:

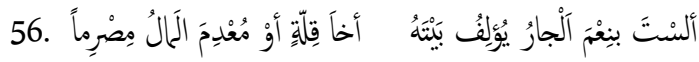

(Al-Anbari, n.d., p. 97)

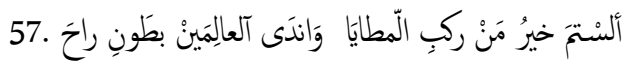

(Arafa, 1984, p. 114)

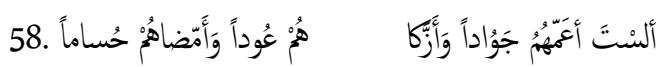

(Wahba, 1974, p. 478)

\section{ANALYSIS}

This section is devoted to the analysis of praising at three aspects: pragmatic, semantic and syntactic with reference to different aayas from different suras in the Glorious Quran.

Text 1

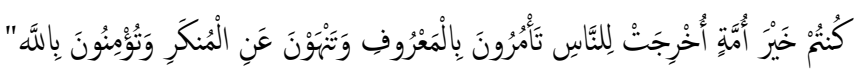

$$
\begin{aligned}
& \text { "(ال عمران/210 (110) }
\end{aligned}
$$

"We are the best. Of Peoples, evolved. For mankind, Enjoining what is right,

Forbidding what is wrong, And believing in Allah." (Ali, 2001, p. 155)

The pragmatic aspect of this aaya shows that Allah implicitly praises the People of the Book especially Muslims since they have the strongest faith in Him; doing right, being an example to others to do right, and having the power to see that the right prevails; and eschewing wrong, being an example to others to eschew wrong, and having the power to see that wrong and injustice are defeated (Al Tabatabai, 1962, p. 415).

Semantically speaking, this aaya uses one of the expressions of praise أََُّّة as an adjective to praise such kind of people who believe in Allah as one true God and are described by the Prophet Muhammad as:

$$
\text { (أتتم زينتم سبعين أمة أتتم خيرها وأكرعا على الله) }
$$

Text 2

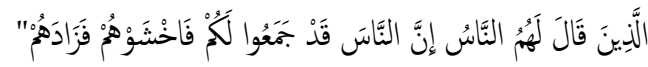

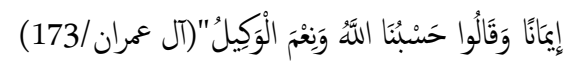

"Men said to them: Against you, so fear them":

"A great army is gathering But it (only) increased, Their Faith; they said:

"For us Allah sufficeth, And He is the best. Disposer of affairs." (Ali, 2001, p. 173)

In this aaya, Allah is praised by the followers of His Messenger Muhammad when the leader of the unbelievers says that he would fight His Messenger at Badar Battle. Later, he sends one of his guards to threat Muslims and advise them to return to al Madinah but they reject his advice and decide to fight with their Prophet and depend on Allah since $\mathrm{He}$ is the best God to rely on (Al Razi, 2000, p. 81).

Pragmatically, this aaya expresses the illocutionary force of praising through using the explicit performative verb namaa. At the syntactic structure, this aaya makes use of a declarative sentence which consists of the explicit verb of praise and a

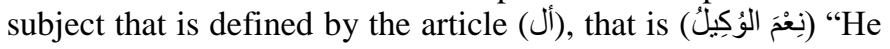
is the best disposer of affairs".

Text 3

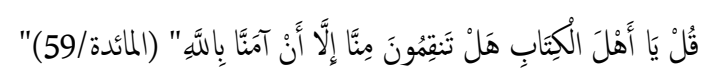

"Say: "O People of the Book! Do ye disapprove of us For no other reason than. That we believe in Allah," (Ali, 2001, p. 267)

It is suggested according to People of the Book that the persecutors will richly deserve to be punished in the fire of Hell for their faith in the one true God. And because of their ignorant they consider their belief in Allah as a horrible sin that threats their position, therefore, they want to take revenge upon them and blame them.

Pragmatically, this aaya reveals praise by blame which is

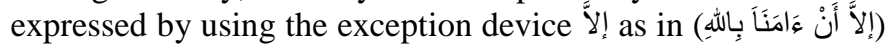
"For no other reason than that we believe in Allah" in order to praise those true believers in Allah who are praiseworthy by 
blaming them. At the syntactic structure, the interrogative sentence is used here to convey the illocutionary force of praising through the question device هَ.

\section{Text 4}

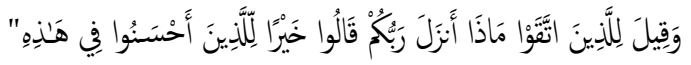

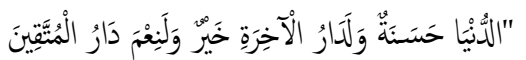

"To the righteous(When) it is said, "What Is it that your Lord Has revealed ?"

They say, "All that is good." To tho. Who do good, there is good In this world, and the Home. Of the Hereafter is even better And excellent indeed is the Home . Of the righteous -" (Ali, 2001, p. 644)

This aaya presents a contrast between the godly and ungodly people where the ungodly in their levity and their deliberate rejection of guidance find no profit from Allah's revelation. Unlike them, the godly people find good everywhere in this world and in the Hereafter, because they understand Allah brings down the Glorious Quran to save them and they are in accord with the truths around them (Al Tabarsi, 1958, p. 175).

The pragmatic aspect of this aaya reveals that Allah explicitly praises the Home of the godly people through using the explicit verb namaa to emphasize that it is a suitable and better place for them. At the semantic implication, this aaya makes use of the expression حَنَنَُّ "good" to praise such good people as a reward for what they have done in their life.

The syntactic structure of this declarative sentence comprises of the explicit verb and a subject which must be added to

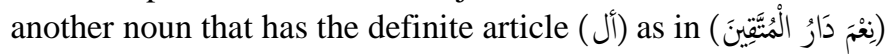
"excellent indeed is the Home of the righteous". In addition,

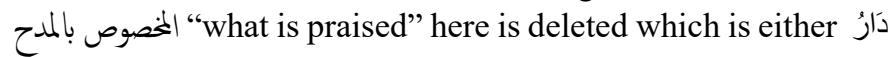

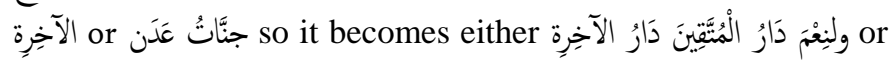

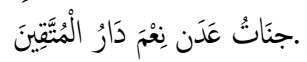

\section{Text 5}

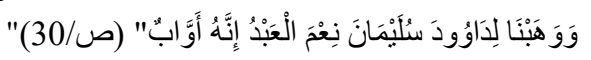

"To David We gave Solomon (for a son)- How excellent in Our service!

Ever did he turn (to Us)!" (Ali, 2001, p. 1168)

This aaya is used to bless the Prophet Solomon as a righteous king, not as an idolator, doing "evil in the sight of the Lord" (1 Kings, 11:6). Like his father David, Solomon was also most meticulous in not allowing the least motive of self to be mixed up with his spiritual virtues. Further, he was fond of horses, he had great armies and wealth, but he used them all in Allah's service (Ali, 2001).

This aaya, from a pragmatic perspective, conveys the illocutionary force of praising through the verb namaa to praise Solomon who was a great King. Semantically, the lexical item awab is used here as an adjective to commend the Prophet Solomon since he always turned to Allah in all conditions.

Syntactically speaking, Allah explicitly praises His Prophet Solomon by using this pattern of a declarative sentence which consists of the verb of praise namaa and a definite subject with

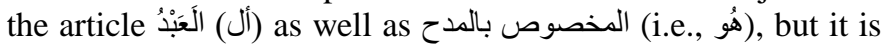

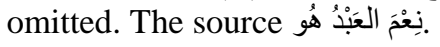

Text 6

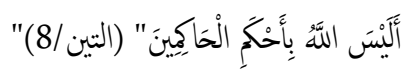

"Is not Allah. The wisest of Judges? (Ali, 2001, p. 1670)

This aaya promises the unbelievers that Allah will judge them according to their sins since $\mathrm{He}$ is wise and just. Therefore, the righteous have nothing to fear, but the evil ones cannot escape from His punishment (Al Zamakhshari, n.d, p. 765).

Semantically, the lexical item أحْكَم أفعل) of the form is used here as an adjective to extol Allah for His justice and wisdom. The form of this aaya, at the syntactic structure, is carried out by interrogative sentence through the particle أَلْئسن for interrogation can be used to express the illocutionary force of praising.

\section{CONCLUSION}

Throughout the study, the researcher arrives at the following conclusions:

1- The analysis clarifies that praise in Arabic can be applied to religious texts by analyzing the pragmatic, semantic and syntactic aspects. This means that such religious texts give suitable samples of the expressive acts of praising.

2- Throughout the analysis, it is concluded that praise is expressed in more than one form in the Arabic language and the explicit and implicit forms are often used in the Glorious Quran.

3- With regard to the tense of the performative verbs that are used to express praise in Arabic the study concludes that Arabic performative verbs of praise can be expressed only by using the past tense.

4- It is also concluded that praise in Arabic can be determined not only by declarative sentence but also by other type such as interrogative.

\section{REFERENCES}

Abdul Baqi. Mohammad Fouad. (1959). Almejm alfahrsiu lialfath alquran alkarim. Cairo: Matabie Alshaeb.

Al Ainsari, 'Abi Muhammad Bin Eabd Allh. (1996). 'Awdah almasalik 'iilaa alfiat abn malik. Vol. 1. Beirut: Dar Alkitab Alearabiu.

Al Aistirabadiu, Radi Aldiyn Muhammad Bin Alhasan. (1975). Sharah alkafiat abn Alhajib. Vol. 1. Beirut: Kutub Al-Eilmia.

-------.(n.d.). Sharah alkafiat. Vol. 2. Beirut: Kutub Al-Eilmia.

Ali, A. (2001). The meaning of the Holy Qur'an. Beltsville: Amana Corporation.

Al Anbari ,'Abi Albarakat Eabd Alruhmn Bin Muhmad. (n.d.). Kitab 'asrar alearabia. Damascus: Matbueat Almjme Aleilmii Alearabii.

Anys, Ibrahim. (1966). Min 'asrar allugha. Cairo: Maktabat Alainjilu Almisria.

Ibn Aqil, Baha Al-Din. (1965). Sharah ibn aqeel ealaa alfiat ibn malik. Vol. 2. Cairo: Matbaeat Alsaeada. 
Arafa, Abdul Aziz. (1984). Min balaghat alnatham alerby: Dirasa tahlilia limasayil eilm almaeani. Vol. 2. Beirut: Ealim Alkutub.

Al Asefahani, Alhusayn Bin Muhammad. (n. d.). Almufradat fi ghurayb alquran. Beirut: Dar Almaerifa.

Ibn Asfour, Ali Bin Mu'men. (1980). Sharah jamal alzajaji, alsharah alkabir. Baghdad: Matabie Muwasasat Dar Alkutub. --(1986).Almuqarab. Baghdad: Mutbaeat Aleani.

Ateeq, Abdul Aziz. (1970). Eulim albadie. Beirut: Dar Alnahda Alearabia.

Al Baghdadi, Abdul Qadir bin Omar. (n. d.). Khizanat al'adab walib libab lisan alearab Beirut: Dar Sader

Bybrs, Ahmed Samir; and Sawid, Abdullah. ～(1984). Alearabia lighayr alearab. Tunisia: Aldaar Alearabii Lilkitab.

Al Eayniu, Badr Al-Din Mohammad. (1990). Sharah almarah fi altasrif. Baghdad: Matbieat Alrasheed.

Al Firuzabadi, Majd El Din Mohammad. (1970). Basayir thu altamyiz fi litayif alkitab aleaziz. Vol. 6. Cairo: Matbaeat Sharikat Alaielanat Alsharqia.

Bin Al Hajib, 'Abi Eamrw Euthman. (1980). Sharah alwafia natham alkafia. Najaf: Mutbaeat Aladab. Mutbaeat Almaeani.

Al Hashmi, Ahmad. (1970). Jawahir albalagha fi almaeani walbayan walbadie. Beirut: Dar 'Iihya' Alturath Alearabiu.

Hassan, Abbas. (n.d.). Alnahw alwafiy. Vols. 2, 3. Cairo: Dar Al Ma'arif.

Bin Hian, Athyr Aldiyn Muhammad. (1989). Airtishaf aldurb min lisan alearab. Vol. 3. Cairo: Matbieat Almadanii.

Al Jawhari, Ismail bin Hammad. (1979). Alsahah, taj allugha wasahah alearabia. Beirut: Dar Aleilm Lilmalayin.

Al Jazem, Ali; and Amin, Mustafa. (1969). Albalagha alwadiha. Albayan walmaeani walbadie. Cairo: Matabie Dar Almaearif.

Al Jurajaniu, Abdul Qader. (1982). Kitab almuqtasid fi sharah alaidah. Baghdad: Dar Alrasheed Lilnashr.

Al Khdry, Muhammad. (1940). Hashia alkhdry ealaa sharah alshaykh abn eaqil lialfiat abn malik. Cairo: Matbaeat Mustafa Albabi Alhalbii waiwladih.

Makram, Abdel Aal. (1975). Tatbiqat nahwia wabilaghia. Vol. 2. Kuwait: Dar Albihwth Aleilmia. Al Manjad fi allugha. (1969). Beirut: Dar Almashriq.

Al Manjad fi allugha. (1969). Beirut: Dar Almashriq.

Abn Manthur, Abi AlFadl Gamal El Din. (1955). Lisan alearab. Beirut: Dar Beirut

Al Maraghi, Ahmad Mustafa. (n.d.). Eulum albilagha albayan walmaeani walbadie. Cairo: Almaktaba Alearabia.

Matlub, Ahmad. (1964). Albalagha eind alsukkakii. Baghdad: Dar Altadamun. --.(1980).Asalib balaghia. Alfasaha- albalagha almaeani.Kuwait: Wikalat Almatbueat.

Matlub, Ahmad;and Al Basir, Hasan. (1999). Albalagha waltatbiq. Baghdad: Wizarat Altaelim Aleali Walbahth Aleilmii.

Al Mubarid, Muhammad. (1937). Alkamil fi allugha waladb. Cairo: Matbaeat Mustafaa Albabi Alhalbi. --.(1979). Almuqtadab.Vol. 2. Cairo: Lajnat Alturath Al'iislamii.

Nahr,Hadi. (1978). Altarakib allughawia. Baghdad: Matbaeat Al'iirshad.

Al Qaisi, Makki. (1975). Mushakil aerab alquran. Baghdad: Mutbieat Salman Alaethami.

Al Qazwaini, Jalaluddin Mohammad. (1904). Altalkhis fi eulum albalagha. Cairo: Almaktaba Altija Alkubraa. - Cairo: Matbaeat Alsana Al Muhammadiyah.

Bin Qutaiba, Abu Mohammad. (1978). Tafsir ghurayb alquran. Beirut: Dar Alkutub Aleilmia.

Al Raajihiu, Abda. (1985). Altatbiq alnahwi. Beirut: Dar Alnahda Alearabia.

Al Razi, Fakhruddin Mohammad. (2000). Altafsir alkabir 'aw mafatih alghayb. Vols. 9, 16. Beirut: Kutub Al-Eilmia.
Al Sabuniu, Abdel Wahab. (n.d.). Allibab fi alnahw. Beirut: Maktabat Dar Alshrq.

Al Saliliu, Muhammad Bin Eisaa. (1986). Shifa' alealil fi aydah altashil. Beirut: Dar Alnadwa Aljadida.

Ibn Al Siraj, Abu Bakr Mohammad. (1987). Al'asl fi alnahw. Vol. 1. Beirut: Muasasat Alrisalat Liltabaea.

Al Suyuti, Jalaluddin Abdul Rahman. (1380). Alaitiqan fi eulum alquran. Vol. 3. Cairo: Matbaeat Almashhad.

Al Tabarsi, Abu Ali AlFadl. (1958). Majmae albayan lieulum alquran. Vols. 3, 6. Cairo: Dar Altaqrib Bayn Almadhahib Al'iislamia.

Al Tabatabai, Mohammad Hussein. (1962). Almizan fi tafsir alquran. Vols. 3, 16. Tahran Dar Alkutub Al'iislamia.

Al Tifatazaniu, Saad Eddin. (n.d.). Sharah almukhtasir. Vol. 1 Beirut: Muasasat Dar Albayan Alearabii.

Wahba, Maagdi. (1974). A dictionary of literary terms. Beirut: Librairie du Liban.

Wright, W. (1967). A Grammar of the Arabic Language. (3rd ed.) Cambridge: Cambridge University Press.

Bin Yaeish, Muafaq El Din. (n. d.). Sharah almufasil. Vol. 5. Cairo: Iidarat Altibaea Almuniria.

Al Zajaji, Abu Alqasim Eabd Alrahmin. (1988). Aljamal fi alnahw. Beirut: Dar Al'amal.

Bin Zakaria, Abu Alhasan Ahmad. (1979). Maqayis allugha. Vols. 1, 2. Beirut: Dar Alfikr.

Al Zamakhshari, Abu Alqasim Ja Allah. (n. d.). Alkishaf ean haqayiq altanzil waeuyun al'aqawil fiwujuh alttawil. Vols. 2, 4. Beirut: Dar Almaerifa. 